\title{
1-Naphthaleneacetic Acid (NAA) Reduces Sucker Growth in European Hazelnut (Corylus avellana L.)
}

Ryan J. Hill and David R. King

Department of Horticulture, Oregon State University, 4017 Agriculture and Life Sciences Building, Corvallis, OR 97331

\section{Richard Zollinger}

Product Development Northwest Region, AMVAC Chemical Corporation, 4695 MacArthur Ct Ste 1200, Newport Beach, CA 92660-8859

\author{
Marcelo L. Moretti \\ Department of Horticulture, Oregon State University, 4017 Agriculture \\ and Life Sciences Building, Corvallis, OR 97331
}

Additional index words. basal sprout, filbert, plant growth regulator

\begin{abstract}
Three 2-year field studies were conducted to evaluate 1-naphthaleneacetic acid (NAA) as a suppressant of suckers in European hazelnut (Corylus avellana L.). Treatments were basal-directed applications of NAA at 5,10 , and $20 \mathrm{~g} \cdot \mathrm{L}^{-1}$ a.i. applied once per season, and two sequential applications of NAA $10 \mathrm{~g} \cdot \mathrm{L}^{-1}$ a.i., 28 days apart, compared with 2,4-D (3.8 $\mathrm{g} \cdot \mathrm{L}^{-1}$ acid equivalent), and a nontreated control. Treatments were applied early in spring and repeated the following year. Both NAA and 2,4-D delayed sucker growth by 1.2- to 3.0-fold compared with the nontreated control, and response varied with experimental site and year. Sequential treatments of NAA significantly reduced sucker height and fresh weight 120 days after treatment. NAA applied in sequential treatments increased tree trunk crosssectional area and canopy volume in two of the three experimental sites. Yield of hazelnuts increased when suckers were removed with NAA or 2,4-D compared with nontreated. Results indicate that NAA is an effective option to control suckers in hazelnuts and can help reduce herbicide and labor in sucker control.
\end{abstract}

The natural form of European hazelnut (Corylus avellana L.) is a multistemmed bush. Hazelnuts can be trained into single-trunk trees, which facilitates mechanized orchard maintenance and harvest, increasing yield (Mehlenbacher and Smith, 1992). Maintenance of the single-trunk form requires persistent control of basal sprouts or suckers. In Oregon, chemical control is the most common means of control for hazelnut suckers. Four to eight applications per growing season are required (Olsen and Peachey, 2013; Souza and Moretti, 2020). The herbicides currently labeled for

Received for publication 4 Aug. 2021. Accepted for publication 6 Oct. 2021.

Published online 19 November 2021.

AMVAC Chemical Corporation provided financial support for this work. The authors thank Christensen Farms, OO Agriculture Inc, and Birkemeier Farms \& Nursery for field study collaborations. We also acknowledge the assistance of visiting undergraduate student Arnaldo Marques Caldeira da Silva from University of São Paulo, Piracicaba, Brazil.

R.J.H. and D.R.K. are Faculty Research Assistants.

M.L.M. is an Assistant Professor.

M.L.M. is the corresponding author. E-mail: marcelo.moretti@oregonstate.edu.

This is an open access article distributed under the CC BY-NC-ND license (https://creativecommons. org/licenses/by-nc-nd/4.0/). inhibition or wilting and tissue necrosis and death (Grossmann, 2010). Also, NAA is a non-volatile compound (Pohanish, 2015).

Previous studies in hazelnut have shown that 5 and $10 \mathrm{~g} \cdot \mathrm{L}^{-1}$ a.i. of NAA caused wilting of treated suckers and reduced new sucker sprouts without injuring the trees within $30 \mathrm{~d}$ after treatment (Dolci et al., 2000). When this study was initiated, NAA was not labeled for hazelnut sucker control, but its low volatility could make it an attractive alternative to 2,4D. However, there was no information on the long-term impact of NAA on sucker control or hazelnut tree tolerance. In the present study, the efficacy of NAA (ethyl ester) for sucker control and its impact on tree growth were evaluated over 2 years. The objective of this study was to assess the effect of NAA on hazelnut sucker growth when applied as bandspray to tree bases.

\section{Materials and Methods}

Field studies. Three young hazelnut orchards located in commercial fields near Amity, Canby, and Corvallis in Oregon's Willamette Valley were used for the study. The Amity trial was conducted in a 2-year-old irrigated orchard planted with cultivars McDonald and Wepster hazelnuts, spaced at $3 \times 6 \mathrm{~m}$. The Canby trial was conducted in a 1-year-old rainfed orchard planted with cultivar McDonald, and 'Wepster' hazelnuts spaced at $3 \times 6 \mathrm{~m}$. The Corvallis study was conducted in an irrigated 5-year-old nursery of cultivar Jefferson hazelnuts spaced at $1.5 \times$ $1.5 \mathrm{~m}$. Suckers were removed manually the winter before the experiment was initiated.

At each location, six treatments were compared, including a single application of NAA (Tre-hold A-112 Sprout Inhibitor; AMVAC, Newport Beach, CA) at 5, 10, and $20 \mathrm{~g} \cdot \mathrm{L}^{-1}$ a.i. at $280 \mathrm{~L} \cdot \mathrm{ha}^{-1}$, or the equivalent of 1.4 , 2.8 , and $5.6 \mathrm{~kg} \cdot \mathrm{ha}^{-1}$ a.i., respectively. Additional treatments included two sequential applications of NAA at $10 \mathrm{~g} \cdot \mathrm{L}^{-1}$ a.i. $(2.8 \mathrm{~kg}$. $\mathrm{ha}^{-1}$ a.i.) at $28 \mathrm{~d}$ intervals, a single application of 2,4-D $3.8 \mathrm{~g} \cdot \mathrm{L}^{-1}$ a.i. (1.07 $\mathrm{kg} \cdot \mathrm{ha}^{-1}$ acid equivalent) (Saber, Loveland Products, Loveland, CO). All treatments included non-ionic adjuvant at $0.25 \% \mathrm{v} / \mathrm{v}$ (Rainier, Wilbur Ellis, Fresno, CA) as recommended by manufacturer, and tap water was used as carrier.

Treatments were applied using a $\mathrm{CO}_{2}$ pressurized backpack sprayer calibrated to deliver $280 \mathrm{~L} \cdot \mathrm{ha}^{-1}$ at $275 \mathrm{kPa}$ applied at 3.2 $\mathrm{km} \cdot \mathrm{h}^{-1}$. The spray boom was equipped with three TeeJet AI-11002 nozzles (TeeJet Technologies, Glendale Heights, IL) placed at 45 $\mathrm{cm}$ above the ground covering $1.5 \mathrm{~m}$ on each side of the tree row. An application consisted of a single pass on each side of the trees. First application started in May 2019; applications were repeated in Apr. 2020. A nontreated control was included, in which suckers were not removed until the end of the season. The experiment was a randomized complete block design with four replicates. Each experimental plot consisted of 10 trees in Amity and Canby and six trees in Corvallis.

Data collection. Assessments included visual estimates of sucker control (\%) using a 
Table 1. Rating scale for visual estimate of hazelnut sucker control by NAA and 2,4-D.

\begin{tabular}{ll}
\hline 0 & No injury or growth stunting, sucker growth is normal. \\
10 & Slight reduction in sucker growth and cupped leaves. \\
20 & Moderate injury, minimal reduction in sucker growth, and leaf cupping observed. \\
30 & Sucker stunting observed. Epinasty and twisting of internodes. Leaf necrosis present. \\
40 & Leaf necrosis is apparent. Sucker stunting is more noticeable. \\
50 & Incidence of necrotic leaves increases and very high reduction in sucker growth. \\
60 & Signs of sucker death with severe reduction in growth. New growth inhibited. \\
70 & Reduction in sucker growth more apparent. All leaves are malformed, and some have been dropped. \\
80 & Severe sucker injury and growth reduction. Epinasty and deformation observed. Leaves \\
& present are mostly necrotic. \\
90 & Sucker death observed. Majority of suckers are without leaves; those presents are necrotic. \\
100 & All suckers are wilted and dead.
\end{tabular}

rating scale detailed in Table 1 , adapted from Robinson et al. (2013). Sucker height $(\mathrm{cm})$ and proportion of tress with suckers, or incidence $(\%)$, were also recorded. Evaluations were performed at $0,7,14,21,28,60,90$, and $120 \mathrm{~d}$ after treatment (DAT) during each year of the study. At 120 DAT, suckers were cut to ground level, and the fresh weight was recorded. Tree trunk caliper was measured at $0.5 \mathrm{~m}$ aboveground level in the fall of 2019 and again in the fall of 2020. Trunk caliper was converted to trunk cross-sectional area. Tree canopy volume was measured in the summer of 2020 . We recorded plant height and width parallel and perpendicular to the planting row; volume was calculated by multiplying each recorded value. Measurements were collected from all plants and averaged within research plots. Yield data were collected at the Corvallis site in 2020 by harvesting nuts from all trees per plot with a pushbehind harvester (Bag-a-Nut, Jacksonville, FL). The other sites did not yield or had insufficient yield due to the juvenility of the trees.

Data analysis. Statistical analyses were performed using R v 4.0.3 (R Core Team, 2021). Sucker height was analyzed in a linear mixed model using R package LME4 (Bates et al., 2015). Experimental sites, year, plant cultivar, and treatment were considered fixed effects, whereas experimental blocks and their interactions were treated as random effects. Data were averaged across cultivars at each location because there was no interaction of treatment and cultivar, and the interest was to develop a broad recommendation applicable to multiple hazelnut cultivars (Moore and Dixon, 2015).

The response of sucker height over the growing season was analyzed as a nonlinear regression using the DRC package (Ritz et al., 2015). Only the trees with suckers were included in the analysis. Cumulative growing degree days were calculated by the Baskerville-Emin method (Baskerville and Emin, 1969), with a $10^{\circ} \mathrm{C}$ threshold using climate data from the National Oceanic and Atmospheric Administration (NOAA). Caleach year.

A four-parameter log-logistic model was selected based on Akaike's information criterion (AIC) (Ritz et al., 2015). The parameters included upper limits ( $\max )$, the time required to reach $50 \%\left(t_{50}\right)$ of maximum height, and the curve slope at $t_{50}$ for each treatment (full model). A full model was compared with a culations were initiated on the first day of model with shared parameters (reduced model). A reduced model was selected based on smaller AIC values and lack-of-fit tests. The parameter for each treatment was compared with the nontreated control using the "compParm" procedure from the DRC package. A ratio smaller than one indicates a reduction and larger than one an increase in the coefficient. The ratio was deemed significant when the z-test at $P \leq 0.05$ (Ritz et al., 2015).

Sucker control and incidence were analyzed using a generalized linear mixed model in the R package glmmTMB (Brooks et al., 2017) and sucker weight and crop safety data were analyzed with a linear mixed model using R package LME4 (Bates et al., 2014) with Tukey's honestly significant difference test used for multiple comparisons. Fixed factors assessed were treatment and sucker presence at the time of treatment. Experimental blocks and their interactions were random factors in the analysis. A comparison was deemed significant if the $P$ value was lower than 0.05 .

\section{Results}

Experimental site and year were significant effects for sucker height, and sucker height data were analyzed independently by site and year combination. A nonlinear regression relating sucker height to growing degree days for each treatment, experimental site, and year
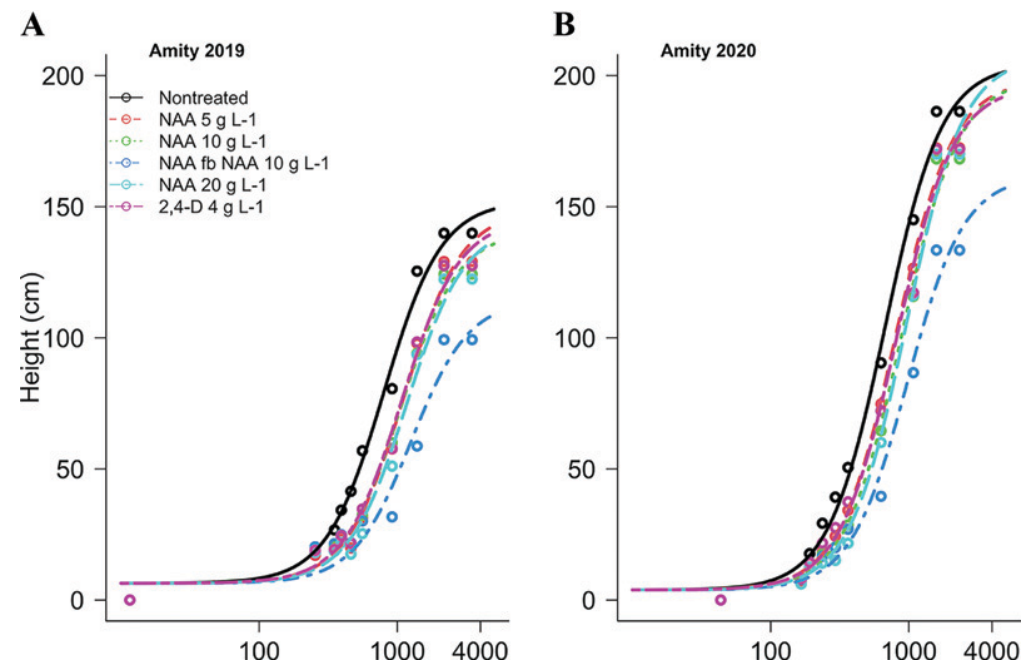

Fig. 1. Observed data points and nonlinear regression model for sucker height over growing degree days at the Amity experimental site in (A) 2019 and (B) 2020. Hazelnut suckers were treated with NAA or 2,4-D. of the season. The maximum heights of suckers treated with NAA at $5 \mathrm{~g} \cdot \mathrm{L}^{-1}$ and 2,4-D at $4 \mathrm{~g} \cdot \mathrm{L}^{-1}$ were not different from nontreated suckers. Treatment with NAA or 2,4-D increased the time required for the suckers to reach $50 \%$ of the upper limit $\left(\mathrm{t}_{50}\right)$ compared with the nontreated control by 1.3- to 1.6fold, and a greater delay in sucker growth occurred with the sequential application of NAA at $10 \mathrm{~g} \cdot \mathrm{L}^{-1}$. The upper limit of sucker height was affected only by the sequential application of NAA in Amity in 2020, where sucker height was $80 \%$ of the nontreated control (Table 2). As observed in the previous year, NAA and 2,4-D treatments increased $\mathrm{t}_{50}$ by 1.2- to 1.4-fold compared with the nontreated control; the increase of $t_{50}$ resulting from sequential NAA applications was greatest of the treatments (Fig. 1A and B).

Sequential application of NAA at 10 $\mathrm{g} \cdot \mathrm{L}^{-1}$ reduced maximum sucker height in Canby in 2019 to $60 \%$ of the nontreated, reaching $46 \mathrm{~cm}$ at the end of the season compared with $78 \mathrm{~cm}$. No other NAA treatments affected maximum sucker height, whereas suckers treated with 2,4-D were 1.7-fold larger than the nontreated control at $120 \mathrm{~d}$ $(P \leq 0.05)$. All the treatments increased $t_{50}$ by 1.4- to 3.0-fold compared with the control. A similar response occurred in Canby in 2020 (Fig. 2A and B).

In Corvallis 2019, no treatment reduced sucker height; rather NAA $10 \mathrm{~g} \cdot \mathrm{L}^{-1}$ and 2,4- was fitted using a four-parameter log-logistic model (Fig. 1). The upper limits and $t_{50}$ were calculated for each treatment at each site and year (Table 2). The slope and lower limits were shared among treatments within each experimental site and year (Supplemental Table 1).

In Amity in 2019, hazelnut suckers treated with NAA at 10 or $20 \mathrm{~g} \cdot \mathrm{L}^{-1}$ reached a height of $140-143 \mathrm{~cm}$ at the end of the season (Table 2 ), a reduction by $10 \%$ compared with the nontreated control $(P \leq 0.05)$. The sequential application of NAA at $10 \mathrm{~g} \cdot \mathrm{L}^{-1}$ NAA reduced sucker heights $20 \%$ by the end

HortScience Vol. 56(12) December 2021 
Table 2. Hazelnut sucker height in response to NAA and 2,4-D in field studies in Oregon in 2019 and 2020. Regression parameters for a four-parameter log-logistic regression: upper limit of height ( $\max$ ), time in growing degree days (GDD) to reach $50 \%$ sucker maximum height ( $t_{50}$ ). Studies were conducted in Amity, Canby, and Corvallis, OR, in 2019 and 2020.

\begin{tabular}{|c|c|c|c|c|c|c|c|c|c|c|c|c|}
\hline \multirow[b]{3}{*}{ Treatments $^{\mathrm{z}}$} & \multicolumn{6}{|c|}{2019} & \multicolumn{6}{|c|}{2020} \\
\hline & \multicolumn{3}{|c|}{$\operatorname{Max}^{\mathrm{y}}(\mathrm{cm})$} & \multicolumn{3}{|c|}{$\mathrm{T}_{50}(\mathrm{GDD})$} & \multicolumn{3}{|c|}{$\operatorname{Max}(\mathrm{cm})$} & \multicolumn{3}{|c|}{$\mathrm{T}_{50}(\mathrm{GDD})$} \\
\hline & Mean & \multicolumn{2}{|c|}{ Ratio $^{\mathrm{x}}$} & Mean & \multicolumn{2}{|c|}{ Ratio } & Mean & \multicolumn{2}{|c|}{ Ratio } & Mean & \multicolumn{2}{|c|}{ Ratio } \\
\hline \multicolumn{13}{|l|}{ Amity } \\
\hline Nontreated & 152 & 1.0 & & 800 & 1.0 & & 204 & 1.0 & & 673 & 1.0 & \\
\hline NAA $5 \mathrm{~g} \cdot \mathrm{L}^{-1}$ & 148 & 1.0 & NS & 1118 & 1.4 & $*$ & 198 & 1.0 & NS & 805 & 1.2 & $*$ \\
\hline NAA $10 \mathrm{~g} \cdot \mathrm{L}^{-1}$ & 140 & 0.9 & $*$ & 1060 & 1.3 & $*$ & 198 & 1.0 & NS & 891 & 1.3 & $*$ \\
\hline NAA $10 \mathrm{~g} \cdot \mathrm{L}^{-1} \mathrm{fb}$ NAA & 114 & 0.8 & $*$ & 1259 & 1.6 & $*$ & 162 & 0.8 & $*$ & 974 & 1.4 & $*$ \\
\hline NAA $20 \mathrm{~g} \cdot \mathrm{L}^{-1}$ & 143 & 0.9 & $*$ & 1170 & 1.5 & $*$ & 207 & 1.0 & NS & 962 & 1.4 & $*$ \\
\hline $2,4-\mathrm{D} 3.8 \mathrm{~g} \cdot \mathrm{L}^{-1}$ a.i. & 145 & 1.0 & NS & 1075 & 1.3 & $*$ & 196 & 1.0 & & 815 & 1.2 & $*$ \\
\hline \multicolumn{13}{|l|}{ Canby } \\
\hline Nontreated & 78 & 1.0 & & 1047 & 1.0 & & 128 & 1.0 & & 813 & 1.0 & \\
\hline NAA $5 \mathrm{~g} \cdot \mathrm{L}^{-1}$ & 87 & 1.1 & NS & 1904 & 1.8 & $*$ & 131 & 1.0 & NS & 1119 & 1.4 & $*$ \\
\hline NAA $10 \mathrm{~g} \cdot \mathrm{L}^{-1}$ & 92 & 1.2 & NS & 2296 & 2.2 & $*$ & 116 & 0.9 & $*$ & 1093 & 1.3 & $*$ \\
\hline NAA $10 \mathrm{~g} \cdot \mathrm{L}^{-1} \mathrm{fb}$ NAA & 46 & 0.6 & $*$ & 1503 & 1.4 & $*$ & 95 & 0.7 & $*$ & 1244 & 1.5 & $*$ \\
\hline NAA $20 \mathrm{~g} \cdot \mathrm{L}^{-1}$ & 77 & 1.0 & NS & 2785 & 2.7 & $*$ & 128 & 1.0 & NS & 811 & 1.0 & NS \\
\hline $2,4-\mathrm{D} 3.8 \mathrm{~g} \cdot \mathrm{L}^{-1}$ a.i. & 136 & 1.7 & $*$ & 3189 & 3.0 & $*$ & 120 & 0.9 & NS & 870 & 1.1 & NS \\
\hline \multicolumn{13}{|l|}{ Corvallis } \\
\hline Nontreated & 128 & 1.0 & & 850 & 1.0 & & 148 & 1.0 & & 657 & 1.0 & \\
\hline NAA $5 \mathrm{~g} \cdot \mathrm{L}^{-1}$ & 133 & 1.0 & NS & 982 & 1.2 & * & 147 & 1.0 & NS & 762 & 1.2 & $*$ \\
\hline NAA $10 \mathrm{~g} \cdot \mathrm{L}^{-1}$ & 140 & 1.1 & $*$ & 1079 & 1.3 & * & 150 & 1.0 & NS & 768 & 1.2 & $*$ \\
\hline NAA $10 \mathrm{~g} \cdot \mathrm{L}^{-1} \mathrm{fb}$ NAA & 129 & 1.0 & NS & 1164 & 1.4 & $*$ & 110 & 0.7 & $*$ & 805 & 1.2 & $*$ \\
\hline NAA $20 \mathrm{~g} \cdot \mathrm{L}^{-1}$ & 132 & 1.0 & NS & 1048 & 1.2 & * & 138 & 0.9 & $*$ & 803 & 1.2 & $*$ \\
\hline $2,4-\mathrm{D} 3.8 \mathrm{~g} \cdot \mathrm{L}^{-1}$ a.i. & 144 & 1.1 & $*$ & 1053 & 1.2 & * & 193 & 1.3 & $*$ & 710 & 1.1 & NS \\
\hline
\end{tabular}

${ }^{\mathrm{z}} 1$-Naphthaleneacetic acid (NAA) was applied once each experimental year except in treatment 4 , for which two sequential applications of NAA were made $28 \mathrm{~d}$ apart.

${ }^{\mathrm{y}}$ Coefficients of a nonlinear regression using a four-parameter model upper-upper limit, $\mathrm{t}_{50}$-time required to reach $50 \%$ of upper limit. The lower limit and slope coefficients were common across treatments within experimental site and year. See Supplemental Table 1 for details.

${ }^{\mathrm{x}}$ The ratio of the coefficient for each treatment compared with the nontreated control was used to compare treatment effects. A ratio smaller than one indicates a reduction in hazelnut sucker height, and a ratio greater than one an increase.

*Indicates a significant effect according to a z-test $(P \leq 0.05)$.

D increased it by 1.1-fold. On the other hand, NAA and 2,4-D increased $t_{50}$ by 1.2- to 1.4fold compared with the control. In 2020, NAA at $20 \mathrm{~g} \cdot \mathrm{L}^{-1}$ and sequential application of NAA reduced maximum sucker height to 0.9 - and 0.7-fold of the nontreated height, and all treatments, including NAA, increased $\mathrm{t}_{50}$ by 1.2 -fold. Sequential application of NAA was the only treatment that reduced sucker maximum height in most cases, and
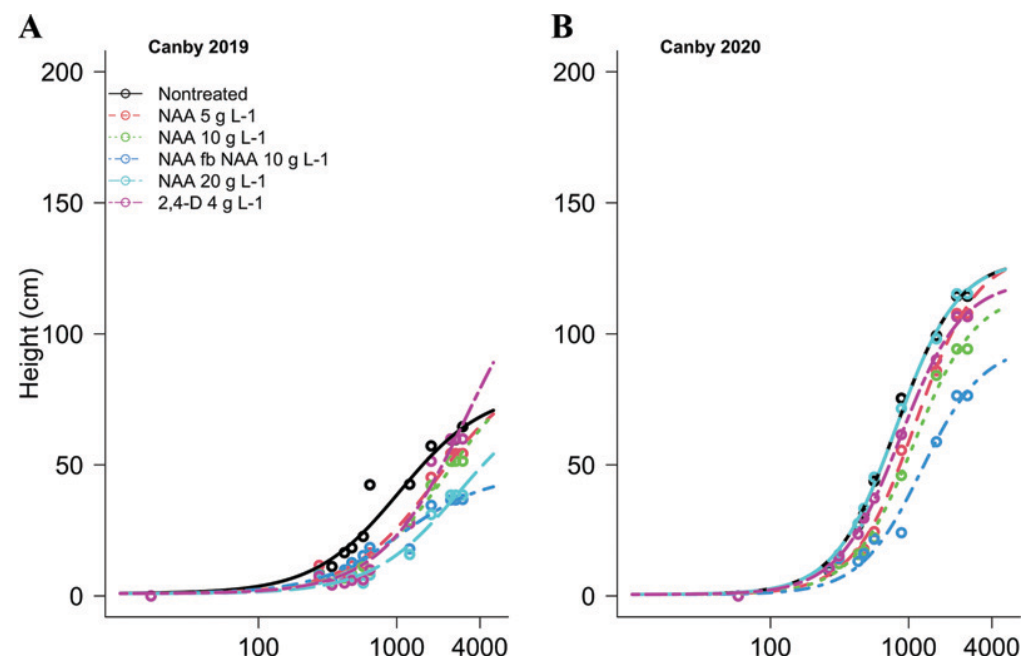

Fig. 2. Observed data points and nonlinear regression model for sucker height over growing degree days at the Canby experimental site in (A) 2019 and (B) 2020. Hazelnut suckers were treated with NAA or 2,4-D.

increased $t_{50}$ in Corvallis in both years (Fig. 3A and B).

The principal effect of NAA and 2,4-D on suckers was growth suppression because control ratings were often at $30 \%$ or less at 60 DAT (Table 3), except in one instance. Necrosis was seldom present, even at early assessments performed at 7 and 14 DAT (data not shown). The suppressive effects of NAA and 2,4-D on sucker growth were noticeable in fresh weight. The fresh weights of suckers were smaller in 2019 compared with 2020 at all sites due to tree juvenility. In Amity, the fresh weight of suckers treated with NAA was 0.7 to $1.7 \mathrm{~kg} /$ tree in 2019 and 2.2 to $6.0 \mathrm{~kg} /$ tree in 2020 (Table 3). The sequential application of NAA reduced fresh weight in all sites and years except in Corvallis in 2019 (Table 3). By contrast, NAA did not impact sucker incidence in any site or year. Sucker incidence increased in Amity and Canby from $70 \%$ to $80 \%$ in 2019 and from $80 \%$ to $90 \%$ in 2020 , respectively, as the orchard became older. About $95 \%$ to $100 \%$ of the trees in the Corvallis orchard had suckers in both years.

Treatment with NAA or with 2,4-D did not reduce tree growth in Amity in either year. Trunk cross-sectional areas ranged from 70 to $79 \mathrm{~cm}^{2}$ in 2019 and 109 to $126 \mathrm{~cm}^{2}$ in 2020 (Table 4). At the Canby site, NAA at 20 $\mathrm{g} \cdot \mathrm{L}^{-1}$ and 2,4-D treatments increased trunk cross-sectional area compared with the control. NAA (except the lower rate) and 2,4-D also increased trunk cross-sectional area in Corvallis. Internode length was unaffected by any treatment and ranged from 9 to $15 \mathrm{~cm}$ among sites (Table 4). Canopy volume increased on plots treated with NAA and 2,4$\mathrm{D}$ in Canby and Corvallis. Hazelnut yields in treatments including NAA at $10 \mathrm{~g} \cdot \mathrm{L}^{-1}$ or more and 2,4-D were 1.6 to $2.2 \mathrm{~kg} /$ tree, or 2- to 2.7-fold greater than the nontreated trees (Table 4). 

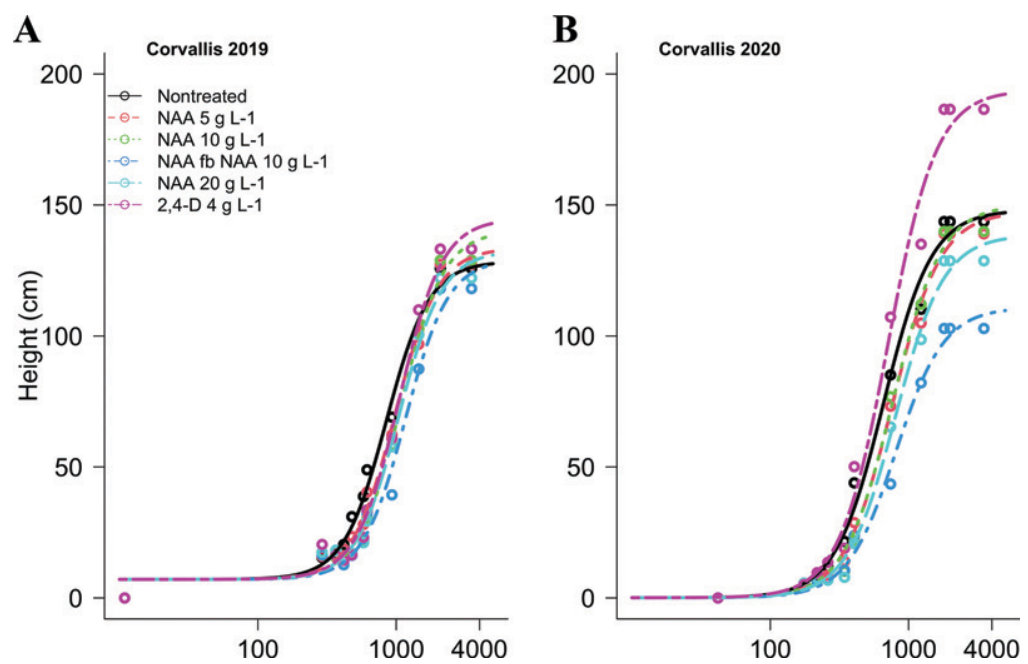

Fig. 3. Observed data points and nonlinear regression model for sucker height over growing degree days at the Corvallis experimental site in (A) 2019 and (B) 2020. Hazelnut suckers were treated with NAA or 2,4-D.

\section{Discussion}

Hazelnuts produce prolific suckers that grow continuously throughout the season, reaching 150 to $200 \mathrm{~cm}$ in $120 \mathrm{~d}$ if left untreated (Table 2, Figs. 1-3). Because of their vigorous growth, sucker control requires multiple herbicide applications during the growing season (Souza and Moretti, 2020). Repeated herbicide applications for sucker control increases the risk of herbicide drift and crop injury. A single application that could effectively suppress sucker growth would reduce the number of yearly herbicide applications, with economic and environmental benefits.
In this study, a single application of NAA at 10 or $20 \mathrm{~g} \cdot \mathrm{L}^{-1}$ or at $2,4-\mathrm{D} 4 \mathrm{~g} \cdot \mathrm{L}^{-1}$ delayed sucker growth compared with the nontreated control in some locations and years (Figs. 1 and 3, Table 2). By contrast, a sequential application of NAA at 10 $\mathrm{g} \cdot \mathrm{L}^{-1}$ consistently reduced sucker height and delayed sucker growth, but sucker fresh weight surpassed $2 \mathrm{~kg} /$ tree by the end of the $120 \mathrm{~d}$ (Table 3). NAA significantly reduced the size of suckers, which would improve the efficacy of other sucker control options like herbicides or pruning. Chemical sucker control is more effective on smaller suckers, and smaller suckers require less effort to control with manual pruning, possibly reducing pruning costs

Dolci et al. (2000) reported the efficacy of NAA in controlling hazelnuts suckers at 5 and $10 \mathrm{~g} \cdot \mathrm{L}^{-1}$, resulting in sucker wilting and complete necrosis 30 DAT when sprayed to runoff. Results herein indicated that NAA up to $20 \mathrm{~g} \cdot \mathrm{L}^{-1}$ suppressed growth, but did not lead to sucker necrosis or wilting (Table 3 ). The contrasting results could be attributed to differences in application method, and NAA rates applied. Spraying to runoff would likely result in greater rates of NAA applied per hectare. NAA causes wilting and necrosis when applied at high rates (Grossmann, 2010).

Trees treated with NAA over two consecutive seasons exhibited no injury or growth reduction (Table 4). In fact, trunk crosssectional area, canopy volume, and yield increased on NAA-treated plants compared with the nontreated (Table 4), suggesting that any potential damage from NAA treatments is outweighed by the benefit from sucker control. The results of this study confirm that NAA is an effective option to suppress hazelnut suckers without negative impacts on crop growth or yield, but even two applications did not eliminate the need for herbicides or pruning. Mixtures of NAA with herbicides could improve sucker control, and mixtures could be more effective than either herbicide or NAA alone, potentially reducing the need of repetitive treatments to control suckers. Furthermore, the use of ammonium sulfate in the spray solution may improve NAA efficacy by increasing NAA uptake even when spray solutions is in neutral $\mathrm{pH}$ (Bukovac et al., 2003). The use of NAA with herbicides

Table 3. Hazelnut sucker control, fresh weight, and incidence after treatments with NAA or 2,4-D in Amity, Canby, and Corvallis, OR, in 2019 and 2020.

\begin{tabular}{|c|c|c|c|c|c|c|c|c|c|c|}
\hline Treatment $^{z}$ & \multicolumn{4}{|c|}{ Control $^{\mathrm{y}}(\%)$} & \multicolumn{4}{|c|}{ Fresh $\mathrm{wt}^{\mathrm{x}}(\mathrm{kg} /$ tree $)$} & \multicolumn{2}{|c|}{ Incidence $^{\mathrm{w}}(\%)$} \\
\hline \multicolumn{11}{|l|}{ Amity } \\
\hline Nontreated & \multicolumn{2}{|c|}{ - } & \multicolumn{2}{|c|}{ - } & 2.5 & $\mathrm{c}$ & 9.0 & $\mathrm{c}$ & 87.5 & 90.0 \\
\hline NAA $10 \mathrm{~g} \cdot \mathrm{L}^{-1}$ & 22.9 & $\mathrm{~b}$ & 3.5 & $\mathrm{c}$ & 1.5 & $\mathrm{~b}$ & 5.5 & $\mathrm{~b}$ & 85.0 & 85.0 \\
\hline NAA $10 \mathrm{~g} \cdot \mathrm{L}^{-1} \mathrm{fb}$ NAA & 66.3 & $\mathrm{a}$ & 36.3 & $\mathrm{a}$ & 0.7 & $\mathrm{a}$ & 2.2 & $\mathrm{a}$ & 90.0 & 87.5 \\
\hline NAA $20 \mathrm{~g} \cdot \mathrm{L}^{-1}$ & 30.6 & $\mathrm{~b}$ & 4.5 & $\mathrm{c}$ & 1.4 & $\mathrm{~b}$ & 4.7 & $\mathrm{~b}$ & 85.0 & 82.5 \\
\hline Nontreated & \multicolumn{2}{|c|}{ - } & \multicolumn{2}{|c|}{ - } & 0.1 & $\mathrm{~b}$ & 0.6 & $\mathrm{~b}$ & 77.5 & 85.0 \\
\hline NAA $5 \mathrm{~g} \cdot \mathrm{L}^{-1}$ & 15.7 & $\mathrm{a}$ & 3.2 & $\mathrm{a}$ & 0.1 & $\mathrm{ab}$ & 0.6 & $\mathrm{~b}$ & 77.5 & 90.0 \\
\hline NAA $10 \mathrm{~g} \cdot \mathrm{L}^{-1}$ & 14.0 & $\mathrm{a}$ & 5.0 & $\mathrm{a}$ & 0.0 & $\mathrm{ab}$ & 0.4 & $\mathrm{ab}$ & 70.0 & 77.5 \\
\hline NAA $10 \mathrm{~g} \cdot \mathrm{L}^{-1} \mathrm{fb}$ NAA & 27.6 & $\mathrm{a}$ & 16.8 & $\mathrm{a}$ & 0.0 & $\mathrm{a}$ & 0.4 & $a b$ & 77.5 & 85.0 \\
\hline NAA $20 \mathrm{~g} \cdot \mathrm{L}^{-1}$ & 24.4 & $\mathrm{a}$ & 8.1 & $\mathrm{a}$ & 0.1 & $a b$ & 0.4 & $\mathrm{a}$ & 82.5 & 82.5 \\
\hline 2,4-D $3.8 \mathrm{~g} \cdot \mathrm{L}^{-1}$ a.i. & 11.2 & $\mathrm{a}$ & 9.0 & $\mathrm{a}$ & 0.1 & $\mathrm{ab}$ & 0.5 & $\mathrm{ab}$ & 75.0 & 80.0 \\
\hline \multicolumn{11}{|l|}{ Corvallis } \\
\hline 2,4-D $3.8 \mathrm{~g} \cdot \mathrm{L}^{-1}$ a.i. & 16.0 & $a b$ & 0.6 & $\mathrm{~b}$ & 1.5 & $\mathrm{~b}$ & 1.8 & $\mathrm{~d}$ & 100.0 & 100.0 \\
\hline
\end{tabular}

${ }_{\mathrm{z}}$ 1-Naphthaleneacetic acid (NAA) was applied once each experimental year except for treatment 4 , for which two sequential applications of NAA were made $28 \mathrm{~d}$ apart.

${ }^{\mathrm{y}}$ Visual estimated of sucker control at $60 \mathrm{~d}$ after initial treatment for each of the experimental years. Means followed by the same letter within columns and experimental site are not statistically different according to Tukey's test $(P \leq 0.05)$.

${ }^{\mathrm{x}}$ Fresh weight of hazelnut sucker biomass per tree.

${ }^{\mathrm{w}}$ Incidence of suckers calculated as number of trees with suckers over total number of trees per plot at the end of each season. 
Table 4. Hazelnut trunk cross-sectional area, internode length, canopy volume, and yield following treatment with NAA or 2,4-D over 2 years in Amity, Canby, and Corvallis, OR, in 2019 and 2020.

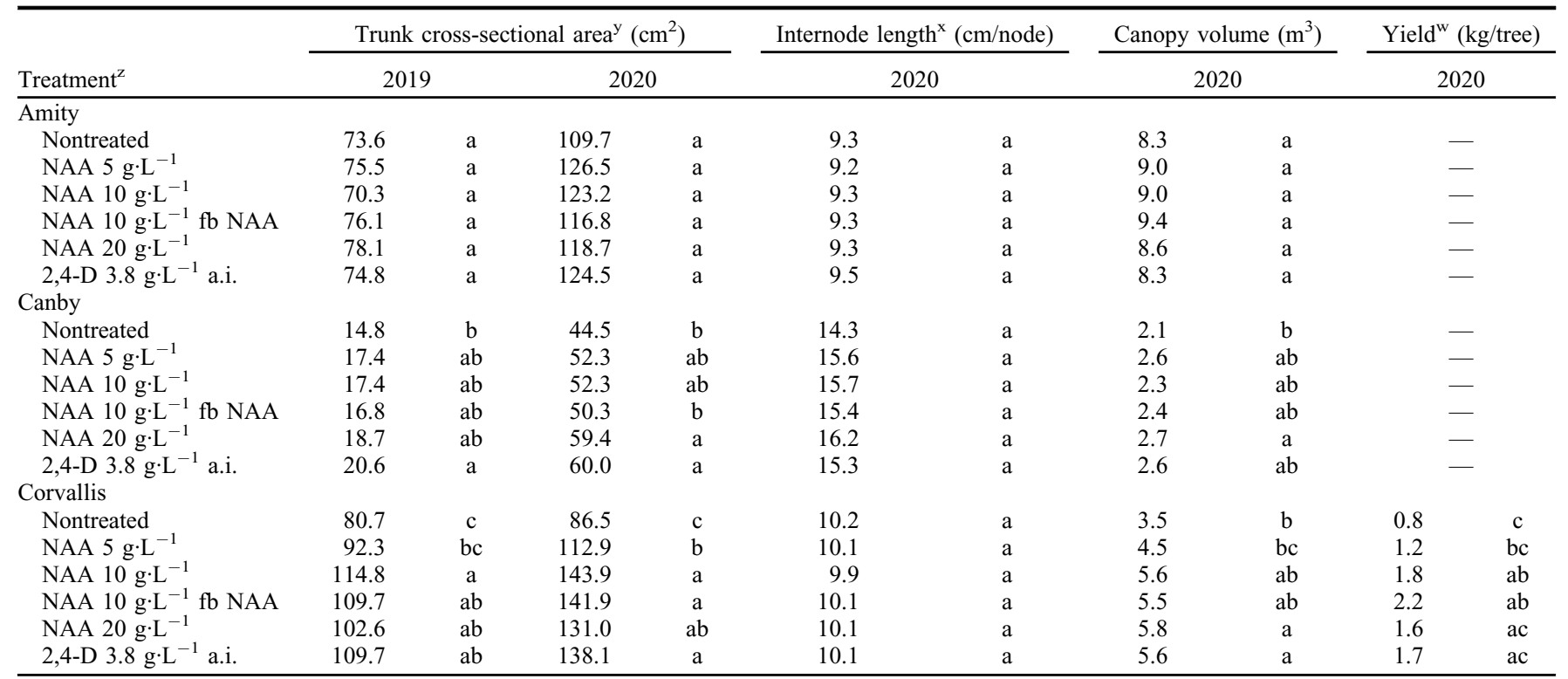

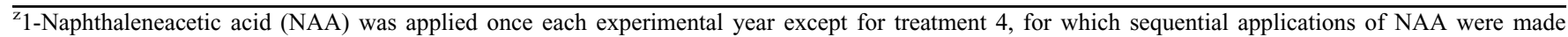
$28 \mathrm{~d}$ apart.

${ }^{\mathrm{y}}$ Trunk cross-sectional area was recorded in winter of each year. Means followed by the same letter within columns and experimental site are not statistically different according to Tukey's test $(P \leq 0.05)$.

${ }^{\mathrm{x}}$ Internode length and canopy volume were recorded at the end of the 2020 year.

${ }^{\mathrm{w}}$ Yield was collected at Corvallis site in 2020. The experimental sites and years did not have measurable yield due to juvenility of the trees.

or pruning methods may reduce the labor and pesticide costs in hazelnut production and reduce environmental impacts.

\section{Literature Cited}

Baskerville, G.L. and P. Emin. 1969. Rapid estimation of heat accumulation from maximum and minimum temperatures. Ecology 50:514517.

Bates, D., M. Maechler, B. Bolker, and S. Walker. 2015. Fitting linear mixed-effects models using lme4. J. Stat. Softw. 67:1-48. <https://www. jstatsoft.org/v067/i01>.

Boswell, S. and C. McCarty. 1974. Basal sprouting of fig trees controlled with NAA. Calif. Agr. 28:14-15.

Brooks, M.E., K. Kristensen, K.J. van Benthem, A. Magnusson, C.W. Berg, A. Nielsen, H.J. Skaug, M. Machler, and B.M. Bolker. 2017. glmmTMB balances speed and flexibility among packages for zero-inflated generalized linear mixed modeling. The R Journal 9:378-400, https://doi.org/ 10.32614/Rj-2017-066.

Bukovac, M.J., R.G. Fader, and P. Luque. 2003. Effects of urea and ammonium nitrate on penetration of NAA through enzymatically isolated tomato fruit cuticular membranes, p. 15-31. In: G. Volgas, R. Downer, and H. Lopez (eds.), Pesticide Formulations and Application Systems 23rd Intl. Symp ASTM Intl., West Conshocken, Pa.
Dolci, M., L. Radicati Di Brozolo, and L. Schellino. 2004. Further experiments on control of sucker growth in hazelnuts (Corylus avellana L.) with new esters of 1-naphthylacetic acid. Acta Hort. 686:271-276, https://doi.org/10.17660/ ActaHortic.2005.686.37.

Dolci, M., L. Schellino, and L. Radicati. 2000. Control of sucker growth in hazelnut with esters of 1-naphthylacetic acid. Acta Hort. 556:431-436, https://doi.org/10.17660/ActaHortic.2001.556.64.

Eynard, I., G. Gay, R. Vallania, P. Occelli, and R. Botta. 1986. Control of sucker growth on Vitis vinifera $\mathrm{cv}$. Merlot with NAA derivatives. Vitis 25:169-177.

Grossmann, K. 2010. Auxin herbicides: Current status of mechanism and mode of action. Pest Manag. Sci. 66:113-120.

Holt, J.S. and W.J. Chism. 1988. Herbicidal activity of NAA (1-naphthaleneacetic acid) on creeping woodsorrel (Oxalis corniculata) in ornamentals. Weed Sci. 36:227-233.

Mehlenbacher, S.A. and D.C. Smith. 1992. Effect of spacing and sucker removal on precocity of hazelnut seedlings. J. Amer. Soc. Hort. Sci. 117:523-526, https://doi.org/10.21273/Jashs.117. 3.523 .

Moore, K.J. and P.M. Dixon. 2015. Analysis of combined experiments revisited. Agron. J. 107:763-771.

Moretti, M.L. 2021. Green sucker control in hazelnuts. In: E. Peachey (ed.), Pacific northwest weed management handbook. Oregon State Univ., Corvallis.

Olsen, J.L. and R.E. Peachey. 2013. Growing hazelnuts in the Pacific Northwest: Orchard floor management, Oregon State Univ. Ext. Serv. AEB EM 9079. Oregon State Univ., Corvallis.

Peterson, M.A., S.A. McMaster, D.E. Riechers, J. Skelton, and P.W. Stahlman. 2016. 2,4-D past, present, and future: A review. Weed Technol. 30:303-345.

Pohanish, R.P. 2015. N, p. 598-617. In: R.P. Pohanish (ed.), Sittig's handbook of pesticides and agricultural chemicals. 2nd ed. William Andrew Publishing, Oxford. https://doi.org/ 10.1016/B978-1-4557-3148-0.00014-5.

R Core Team. 2021. R: A language and environment for statistical computing. R Foundation for Statistical Computing, Vienna, Austria.

Reich, J.E. and H.B. Lagerstedt. 1971. Effect of paraquat, dinoseb and 2,4-D on filbert (Corylus-Avellana L) suckers. J. Amer. Soc. Hort. Sci. 96:554-556.

Ritz, C., J. Strebig, and M.C. Ritz. 2015. Package 'drc'. 16 May 2015. <http://www.bioassay.dk>.

Robinson, A.P., V.M. Davis, D.M. Simpson, and W.G. Johnson. 2013. Response of soybean yield components to 2, 4-D. Weed Sci. 61: 68-76.

Souza, L.L. and M.L. Moretti. 2020. Chemical control of suckers in hazelnut orchards of western Oregon. Weed Technol. 34:863-869, https://doi.org/10.1017/wet.2020.78.

Stover, E., S. Ciliento, and M. Myers. 2006. Trunk sprouting and growth of citrus as affected by NAA, aluminum foil, and plastic trunk wraps. HortScience 41:1612-1615. 
Supplemental Table 1. Regression parameters for a four-parameter log-logistic regression: Slope and minimum (cm). Studies were conducted in Amity, Canby, and Corvallis, OR, in 2019 and 2020. Coefficients of a nonlinear regression were common across treatments within experimental site and year.

\begin{tabular}{lcccr}
\hline & \multicolumn{2}{c}{2019} & & \multicolumn{2}{c}{2020} \\
\cline { 2 - 5 } Treatments & Slope & Min $(\mathrm{cm})$ & Slope & Min $(\mathrm{cm})$ \\
\hline Amity & -2.08 & 6.40 & -2.11 & 3.85 \\
Canby & -1.40 & 0.90 & -1.94 & 0.57 \\
Corvallis & -2.80 & 7.10 & -2.48 & 0.11 \\
\hline
\end{tabular}

